\title{
RITUAL SEMA NAGARI \\ Tradisi Masyarakat Kampar Kiri Hulu
}

\author{
Inda Sari \\ Prodi Studi Agama-Agama Fakultas Ushuluddin, UIN Suska Riau \\ Email: indasari22021998@gmail.com \\ Abu Bakar \\ Prodi Studi Agama-Agama Fakultas Ushuluddin, UIN Suska Riau \\ Email: abu.bakar@,uin-suska.ac.id \\ Khotimah \\ Prodi Studi Agama-Agama Fakultas Ushuluddin, UIN Suska Riau \\ Email: khatimah@uin-suska.ac.id
}

Abstrak:

Ritual Sema Nagari pada masyarakat desa di Desa Tanjung Beringin merupakan tradisi yang bertujuan untuk. membuang musibah yang ada pada warga desa Tanjung Beringin dan juga sebagai pencegah timbulnya perilaku yang bertentangan dengan Agama dan Adat Istiadatyang berlaku di Desa Tanjung Beringin itu sendiri. Kegiatan tolak bala dan mencegah perilaku menyimpang ini, dilakukan melalui perantara yakni ritual Olek Nagari atau Ritual Sema Nagari. Tulisan ini, merupakan deskripsi dari ritual sema nagari di desa tanjung beringin. sejarah pelaksanaan upacara tradisi ritual sema nagari. Prosesi dalam pelaksanaan ritual sema nagari di Desa Tanjung Beringin berawal dari nazar masyarakat kepada Allah, nazar tersebut yaitu jika tidak terjadi bala atau bencana dan tidak. konflik di antara masyarakat maka pada tahun berikutnya akan disembelih satu ekor hewan kerbau dan ziara kuburan yang di sebut dengan sema nagari. Nilai-nilai yang terkandung dalam kegiatan sema nagari yaitu nilai sosial, nilai moral, nilai gotong royong, nilai kerukunan, nilai religi, dan nilai ekonomi, nilai estetika, nilai biburan dan nilai budaya.

Kata Kunci: ritual, sema, nagari

Abstract:

Ritual sema nagari in Tanjung Beringin Village have the same belief, that the Sema Nagari Ritual tradition is very important because this tradition is carried out to preserve the culture of their previous ancestors and also to get rid of calamities that exist on residents of Tanjung Beringin village and also as a deterrent to behavior that is contrary to the prevailing Religion and Customs in Tanjung Beringin Village itself, the activity of repelling reinforcements and preventing deviantbehavior is carried out through intermediaries, namely the Olek Nagari ritual or the Sema Nagari ritual. The history of the of the sema nagari ritual tradition, namely the procession in the implementation of the sema nagari ritual in Tanjung Beringin Village, originated from the people's vows to Allah, the vows that if there is no disaster or disaster and there is no conflict between the community, one buffalo will be slaughtered the following year and ziara graves which are called sema nagari. The values contained in sema nagari activities are social values, moral values, mutual cooperation values, harmony values, religious values and economic values, aesthetic values, entertainment values and cultural values.

Keywords: ritual., sema, nagari 
Indra Sari, dkk: Ritual Sema Nagari...

\section{PENDAHULUAN}

Manusia sebagai makhluk berbudaya yang mempunyai nilai dan keyakinan, manusia mempunyai kebutuhan, seperti kebutuhan ekonomi, kebutuhan rohani, kebutuhan biologis. Kebutuhan tersebut dapat dipenuhi dari alam sekitar, baik lingkungan dan juga masyarakatnya. Manusia harus memiliki kemampuan dalam bisa menjalin hubungan dengan masyarakat dan juga penciptanya. ${ }^{1}$

Kebudayaan tumbuh didalam sistem kehidupan masyarakat, kebudayaan menghasilkan benda dari aktifitas nalar manusia, dimana ia mempunyai kesetaraan dengan bahasa yang juga merupakan benda dari aktifitas nalar manusia tersebut. ${ }^{2}$

Kebudayaan menurut Koentjaraningrat merupakan sekelompok sistem dari cultural system, social system, system kemasyarakatan dan tindakan yang didapatkan dengan cara belajar. Kebudayaan sebagai pengetahuan yang dipakai masyarakat untuk memahami makna terhadap pengalamannya dalam kegiatan sosial, bisa disebutkan untuk menciptakan perilaku kebudayaan. ${ }^{3}$

Kebudayaan secara kompleks berasal dari kehidupan manusia yang tersusun dan didapatkan dengan cara belajar dan juga diwariskan kepada generasi yang selanjutnya. Ralph Linton menjabarkankan lima komponen sistem kebudayaan yaitu terdiri dari kelompok atau masyarakat, lingkungan, baik benda yang diperoleh oleh budaya yang berkaitan, tradisi budaya yang didapat secara bersama dan kegiatan perilaku manusia. ${ }^{4}$

1 Abdulkadir Muhlmammad, Ilmu Budaya Dasar, Jakarta: Cv Fajar Agung, 1992, Ed. 1, Cet. Ke-3, hlmlm.19-20

2 Nur Syam, Madz̧hlmab-madzhlmab Antropologi, Yogyakarta: LKis, 2009, Cet. ke-2, hlmlm.68-69

3 Rusmin Tumanggor dkk, Ilmu Sosial Dan Budaya Dasar, Jakarta: Kencana Prenada Media Group, 2012, Ed. Revisi, Cet. Ke-2, hlmlm.19-22

${ }^{4}$ Bustanuddin Agus, Agama Dalam Keblmidupan Manusia; Pengantar Antropologi Agama, Jakarta, Pt RajaGrafindo Persada, 2006, Ed. 1, hlm.34-35
Kebudayaan terdapat dari sistem nilai- nilai, kepercayaan, dan persepsi abstrak tentang alam semesta yang berada di balik perilaku manusia. ${ }^{5}$ Kebudayaan merupakan keseluruhan tanda kehidupan manusia baik berupa materiel maupun non materiel, kebudayaan akan berkembang dari tahapan yang sederhana menuju tahapan yang lebih kompleks. ${ }^{6}$

Budaya berasal dari karya masyarakat yang menghasilkan teknologi dan berbagai macam benda atau materi yang diperlukan manusia untuk menduduki alam sekitarnya, budaya sebagai hasil rasa, yaitu meliputi jiwa manusia yang mewujudkan segala nilai kemasyarakatan yang diperlukan untuk mengatur masalah kemasyarakatan dalam arti yang luas. ${ }^{7}$

Upacara adat adalah salah satu tradisi masyarakat tradisional yang masih dianggap memiliki nilai-nilai yang masih cukup relevan bagi kebutuhan masyarakat. Selain sebagai usaha manusia untuk dapat berhubungan dengan alam gaib, juga merupakan perwujudan kemampuan manusia untuk menyesuaikan diri secara aktif terhadap alam atau lingkungannya dalam arti luas.

Islam merupakan Agama mayoritas bangsa Indonesia dan telah memberiwarna atau corak peradaban yang khas di Indonesia. Sebagai Agama universal, Islam telah membawa peradabannya sendiri yang berakar kuat pada tradisi yang sangat panjang sejak masa Rasulullah. Ketika bersentuhan dengan situasi lokal dan partikular, peradaban Islam itu tetap

${ }^{5}$ Nur Syam, Madz̧bab-madz̧ab Antropologi, Yogyakarta: LKis, 2009, Cet. ke-2, hlm.37

${ }^{6}$ Elly M.Setiadi, dkk, Ilmu Sosial Dan Budaya Dasar, Jakarta, Kencana PrenadaMedia Group, 2006, Ed.3, hlm.28

${ }^{7}$ Eko Digdoyo, Ilmu Sosial Dan Budaya Dasar, Bogor, Ghlmalia Indonesia, 2015, cet. ke1, hlm.52 


\section{NUSANTARA; Journal for Southeast Asian Islamic Studies Vol. 16, No. 1, Juni 2020}

mempertahankan esensinya yang sejati, walaupun secara instrumental menampakkan bentuk- bentuk yang kondisional. Kebudayaan Islam di Indonesia mempunyai karakteristik tersendiri yang berbeda dengan kebudayaan Islam di Negara- negara Islam dimanapun.

Kehadiran Islam di tengah-tengah masyarakat Indonesia, bukan saja sebagai sistem keagamaan semata, tetapi sekaligus merupakan kekuatan alternatif yang cukup diperhitungkan. ${ }^{8}$ Pengaruh ajaran Agama terhadap kehidupan juga diakui, tetapi semuanya itu adalah ajaran yang diagamakan manusia dan masyarakat yang bersangkutan. ${ }^{9}$

Islam merupakan salah satu Agama yang memiliki pengaruh besar terhadap kehidupan masyarakat Jawa. Masuknya Islam di Indonesia yang secara damai membuat masyarakat menerima Islam meskipun sebelumnya telah berkembang berbagai kebudayaan dan aneka ritual yang bersifat lokal. Masyarakat Jawa sendiri merupakan masyarakat yang sudah memiliki bermacam- macam budaya yang bahkan berkembang sebelum kedatangan Islam. Pasca Islam masuk, tidak serta merta menggeser keberadaan budaya lokal.

Dalam pengamatan sementara terhadap masyarakat desa Pematang Kuing Kecamatan Sei Suka Kabupaten Batu Bara, terlihat adanya faktor-faktor Agama dan konsep-konsep Islam dengan kenyataan perilaku masyarakat di dalam kebudayaan adat istiadat suku Jawa.

Setiap agama membawa misi sebagai pembawa kedamaian dan keselarasan hidup, bukan saja antar manusia, tetapi juga antar sesama mahluk Tuhan penghuni semesta ini. ${ }^{10}$ Agama sebagai suatu sistem kepercayaan, memerlukan masyarakat

${ }^{8}$ Muhammad Yusuf Musa, Islam Suatu Kajian Komprehensif, (Jakarta: Rajawali Pers, 1988), hlm. 6

9 Jamaluddin Kafie, Tuntutan Pelaksanaan Rukun Iman Islam dan Ikhsan, (Surabaya: Penerbit Al-Ikhlas, 1997), hlm. 101-103

10 Dadang Kahlmmad, Sosiologi Agama (Bandung. PT. Remaja Rosdakarya, 2000) hlm : 169 sebagai tempat (locus) memelihara dan mengembangkan agama. Pemahaman, sikap dan perilaku keagamaan senantiasa berkembang mengikuti pemikiran manusia.

Agama dan kitab suci diyakini berasal dari Tuhan, tetapi penafsiran dan pelaksanaannya berlangsung dalam kehidupan masyarakat. Agama meliputi seluruh aspek kehidupan manusia, sedangkan pertumbuhan masyarakat mempengaruhi pemikiran terhadap agama. $^{11}$

Setiap manusia memiliki kebudayaan masing-masing, dan masing-masing manusia tersebut mewujudkan kebudayaan dalam bentuk ide-ide, gagasan, nilai- nilai, norma- norma, peraturan-peraturan yang ada pada masyarakat, dan suatu kompleks aktivitas serta tindakan berpola dari masnusia dalam masyarakat, serta benda-benda hasil karya manusia. ${ }^{12}$ Wujud dari kebudayaan yang di ungkapkan tersebut dapat juga di dalam sistem religi (kepercayaan) yang ada pasa setiap masyarakat, dan juga merupakan kenyataan hidup dari masyarakat yang tidak dapat dipisahkan. Kebudayaan dan adat istiadat yang dimiliki oleh masyarakat merupakan alat pengatur dan memberi arahan kepada setiap tindakan, perilaku dan karya manusia yang menghasilkan bendabenda kebudayaan. Kebudayaan yang ada pada masyarakat juga mempengaruhi pola-pola perbuatan, bahkan juga cara berfikir dari setiap masyarakat.

Hubungan antara alam dan manusia adalah sebuah keharusan yang tidak dapat ditolak, karena hubungan tersebut memiliki nilai-nilai sakral yang sangat tinggi. Hal ini diungkapkan dalam

11 Adeng Muchlmtar Ghlmazali, Antropologi Agama; Upaya Memablmami Keragaman Kepercayaan, Keyakinan dan Agama (Cet. I; Bandung: Alfabeta, 2011), hlm. 34.

${ }^{12}$ Koentjaraningrat, Metode-metode Penelitian Masyarakat (Jakarta, Gramedia, 1981) hlm : 311 
personifikasi mistik kekuatan alam, yakni kepercayaan pada makhluk gaib, kepercayaan pada dewa pencipta, atau dengan mengkonseptualisasi-kan hubungan antara berbagai kelompok sosial sebagai hubungan antara binatang-binatang, burung-burung, atau kekuatan-kekuatan alam.

Upacara adat erat kaitannya dengan ritual-ritual keagamaan atau disebut juga dengan ritual. Ritual adalah alat manusia religius untuk melakukan perubahan. Ia juga dikatakan sebagai simbolis agama, atau ritual itu merupakan "agama dan tindakan". Ritual keagamaan yang dilakukan oleh masyarakat berdasarkan kepercayaan yang dianut oleh masyarakatnya, kepercayaan seperti inilah yang mendorong manusia untuk melakukan berbagai perbuatan atau tindakan yang bertujuan mencari hubungan dengan dunia gaib penguasa alam melalui ritual-ritual, baik ritual keagamaan (religious ceremonies) maupun ritual- ritual adat lainnya yang dirasakan oleh masyarakat sebagai saat-saat genting, yang bisa membawa bahaya gaib, kesengsaraan dan penyakit kepada manusia maupun tanaman.

Pelaksanaan upacara adat maupun ritual keagamaan yang didasari atas adanya kekuatan gaib masih tetap dilakukan oleh sebagian kelompok masyarakat di Indonesia, baik berupa ritual kematian, ritual syukuran atau slametan, ritual tolak bala, dan lain sebagainya. Ritual-ritual ini telah menjadi tradisi dan menjadi bagian dari kehidupan sehari-hari sebagian besar masyarakat karena telah diwariskan secara turun-temurun oleh nenek moyang mereka kepada generasi berikutnya.

Adanya berbagai ritual dan tradisi yang dilakukan telah memperkokoh eksistensi dari agama yang dianut oleh masyarakatnya karena berbagai tradisi yang berkaitan dengan siklus kehidupan berkembang dan menjadi kuat ketika ia telah mentradisi dan membudaya ditengah kehidupan masyarakat, dimana esensi ajarannya sudah include dalam tradisi masyarakat karena tidak sekedar "pepesan kosong” yang tidak memiliki isi dalam sanubari budaya masyarakat.

Salah satu masyarakat yang masih setia mempertahankan tradisi dan ritual nenek moyang mereka adalah masyarakat Desa Tanjung Beringin Kecamatan Kampar Kiri Hulu Kabupaten Kampar Riau (Kenagarian Malako Kociak), yang terdapat di Sungai Subayang ini masih tetap melastarikan ritual-ritual adat sebagai bagian dari kehidupan mereka sehari- hari, meskipun pola hidup modern telah mulai merambah kawasan ini dan mengancam tradisi-tradisi leluhur mereka.

Banyak ritual-ritual yang telah menjadi tradisi dan masih dipertahankan oleh masyarakat Desa Tanjung Beringin seperti ritual Sema Nagari dan Sema Rantau. Ritual Sema Nagari dan Sema Rantau merupakan ritual yang penting bagi masyarakat Desa Tanjung Beringin, dimana sampai sekarang ini masih dipertahankan oleh masyarakat. Tradisi Sema Nagari dan Sema Rantau atau disebut juga dengan badua kadaghek (mendo'a ke kuburan di atas bukit). Masyarakat percaya bahwa dengan melakukan ritual ini keadaan desa atau nagari akan menjadi aman dan terhindar dari berbagai bala.

Ritual Sema Nagari dan Sema Rantau juga merupakan bentuk hubungan atau komunikasi masyarakat terhadap hal-hal gaib guna untuk mencegah perilaku menyimpang yang bisa melanggar nilainilai agama dan adat, seperti berzina, bertengkar, judi, mengambil hak orang lain, kecintaan terhadap adat, sehingga dengan ritual tersebut masyarakat melakukan do'a di makam nenek moyang pertama yang ada di desa tanjung beringin dan juga makam dukun harimau, guna untuk mencengah timbulnya perilakuperilaku yang tidak baik, dengan cara menghimbaukan kepada tiga alam tersebut, jika ada masyarakat yang melanggar perilaku-perilaku tersebut tolong dihukum sipelaku tersebut dengan teguran seperti harimau berbunyi, buaya 
yang menampakkan diri dan juga makhlukmakhluk halus yang menjadi-jadi.

\section{Pelaksanaan Ritual Sema}

Desa Tanjung Beringin merupakan desa yang terletak di wilayah kerajaan Gunung Sahilan, dan nama kenegeriannya yaitu kenegerian Malako Kociak Kerjaan Rantau Kampar Kiri Gunung Sahilan. Ritual sema nagari merupakan kegiatan tahunan yang dilakukan oleh masyarakat Desa Tanjung Beringin (kenagarian Malako Kociak) dengan maksud yang telah turun temurun dari nenek moyang masyarakat, sehingga kegiatan ritual ini masih terjaga adanya dan masih dilukan oleh masyarakat sampai sekarang.

Ritual sema nagari dilakukan oleh orang terdahulu guna untuk yaitu mengucapkan rasa syukur kepada Allah SWT karena dari tahun sebelumnya sampai dengan tahun berjalan keadaan masyarakat masih aman, baik itu hubungan sosial masyarakat maupun hubungan manusia dengan hal-hal gaib, dan tolak bala yaitu menyampaikan kepada mahluk lain supaya tidak menggangu masyarakat, hal ini dilakukan guna untuk kenyamanan dan keamanan di antara masyarakat maupun bentuk kekerabatan dengan makhluk lainnya, sehingga masyarakat terdahulu membuat suatu ritual yang dinamakan dengan ritual sema antau sema nagari.

Masyarakat terdahulu melakukan kegiatan sema nagari tiap tahunnya ketika tidak ada lagi keseimbangan antara manusia dengan manusia dan manusia dengan makluk lain sehingga kegiatan ritual ini dilakukan oleh masyarakat terdahulu dengan memanjatkan doa bersama dan ziarah kuburan orang pertama yang tinggal di desa tanjung beringin dan kuburan dukun harimau. Hal ini dilakukan oleh orang terdahulu supaya ketentraman di antara manusia terjaga dan ketentraman dengan makhluk lainnya juga terjaga keharmonisan dan hal ini dilingkup oleh agama dan adat yang berlaku di desa tanjung beringin.

\section{Prosesi Pelaksanaa Ritual Sema Nagari}

Proses pelaksanaan ritual sema nagari yang ada di desa tanjung beringin kecamatan kampar kiri hulu bersempena dengan kunjungan kerja kerajaan gunung sahilan ada beberapa yang dipersipakan oleh masyarakat yaitu: Pemotongan Kerbau; Perahu Hias (piyau bakajang kain); Masak Daging Kerbau Untuk Makan Bersama; Sesembaha Ritual.

Pertama, Ritual sema nagari yang dilakukan ke makam datuk darah putih (orang pertama menghuni kampung) dan makam dukun harimau merupukan ziarah ke makam tetua kampung terdahulu dan hal ini dilakukan dengan tujuan tertentu. Masyarakat desa tanjung beringin meyakini bahwa ada harimau penjaga kampung sehingga ziara kuburan dan ritual tersebut dilakukan di makan dukun harimau tersebut.

Sesembahan yang dibawa ke makan dukun harimau yaitu hati dan jantung sedikit dari kerbau yang dipotong tersebut di masak dengan cara di bakar dan di campur dengan nasi, lalu sesembahan ini dibungkus dengan dau pisang setelah sampai di makan datuk harimau sesembahan tersebut diletakkan di atas kuburan dukun harimau dan dibuka sedikit daun pisangnnya. Sesembahan untuk harimau penjaga kampung desa tanjung beringin. ${ }^{13}$

Kedua, Ritual sema rantau (sema rantau) atau ritual sema sungai, ritual sema rantau ini sesembahannya yaitu tengkorak kerbau yang dipotong tersebut yang telah diambil daginngnya sehingga yang tersisia tengkorak kerbau. Tengkorak kerbau ini dibawa ke tempat ritual dengan perahu yang telah di hias secara bersama sama. 
Indra Sari, dkk: Ritual Sema Nagari...

Sesembahan ritual sema rantau ini di tenggelamkan atau dimasukkan kedalam sungai pas di perbatasan tanah ulayat desa tanjung beringiin dengan desa gajah beralut. Sesembahan ini pertanda perbatasan tanah ulayat di situ dan yang kedua sesembahan itu merupakan tanda bahwa masyarakat yakin ada penghuni sungai seperti buaya dan bentuk kekerabatan manusia dengan penjaga sungai supaya tidak menggangu masyarakat dan di akhir dari ritual dilaksanakan do'a bersama. ${ }^{14}$

\section{Nilai-nilai Ritual Sema Nagari}

Adat kebiasaan suatu masyarakat dibangun atas dasar nilai- nilai yang dianggap oleh masyarakat tersebut. Nilai-nilai tersebut diketahui, dipahami, disikapi, dan dilaksanakan atas dasar kesadaran masyarakat tersebut. ${ }^{15}$

Tradisi ritual sema nagari di desa tanjung beringin yang sudah dilakukan oleh nenek moyang terdahulu dan sampai dengan sekarang tradisi tersebut masih bertahan di tengah- tengah masyarakat desa tanjung beringin, kegiatan sema nagari dilaksanakan tiap tahunnya dan waktunya tidak ditetapkan dan hanya bila ada kesanggupan masyarakat untuk beriuran untuk pembbelian satu ekor kerbau, prosesi ritual sema nagari dengan memotong hewan ternak satu ekor kerbau.

Pembelian hewan ternak kerbau untuk prosesi ritual sema nagari ini dilakukan dengan iuran per Kepala Keluarga dan daging dari kerbau tersebut di bagi per Kepala Keluarga, sedangkan untuk kepala kerbau daging nya untuk makan bersama di tempat melaksanakan ritual, dan untuk sebagai hati dan jantung kerbau itu disajikan untuk ritual kuburan dukun harimau dengan membakar hati dan jantung kerbau dan di bungkus dengan daun pisang unuk sesajian

14 Wawancara dengan Bapak Yusuf (Keturuan dukun harimau), Kamis, 13 Agustus 2020

15 Prof. H.A.Djazuli. Kaidah-Kaidah Fikih (Kaidah Hukum Islam Dalam Menyelesaikan Masalah Praktis. (Jakarta: Putra Grafika, 2006), Cet. 6 Hlm: 76 harimau yang diletakan di kuburan dukun harimau. ${ }^{16}$

Kearifan lokal masyarakat desa tanjung beringin, meyakini bahwa ada harimau penunggu atau penjaga desa atau nagari, harimau ini menjaga keutuhan masyarakat dan harimau ini mengeluarkan suara apa bila masyarakat tanjung beringin melanggar agama dan adat yang berlaku di masyarakat intinya perilaku yang menyimpang yang dilakukan oleh masyarakat desa tanjung beringin maka harimau penjaga yang diyakini oleh masyarakat akan mengeluarkan suara atau menampakkan badanya kesiapa pun walau tidak pelaku pelanggar agama dan adat istiadat yang berlaku, seperti perilau zina, judi dan perilaku menyimpang yang dilakukan oleh tokoh adat, agama, dan tokoh masyarakat.

Ritual sema nagari ini juga ketika mlaksanakan ziarah kuburan ke kuburan dukun harimau, maka sala satu dukun dan tokoh masyarakat akan menyampai kepada makhluk gaib supaya tidak mengganggu masyarakat desa tanjung beringin seperti penebar penyakit atau menakut-nakuti masyarakat oleh mahluk gaib tersebut, sehingga ritual sema nagari ini termasuk sala satu dari tujuan nya yai tu menyampaikan pesan kepada makhluk halus atau gaip supaya tidak menggangu masyarakat setempat, setelah prosesi ini dilakukan makan dilakukan do'a bersama yang dipimpin oleh pegawai masjid supaya semuanya menjadi aman dan tentram di tengah kehidupan masyarakat.

Setelah prosesi pelaksanaan ziarah kuburan atau yang disebut oleh masyarakat setempat yaitu seman nagari maka prosesi ritual ini dilanjutkan kepa rital sema rantau atau dalam baha setempat (sema atau), sema rantau ini berkaitan air atau sungai,

16 Wawancara dengan Ibu Koluik (Keturuan Dukun Harimau), Jum'at, 14 Agustus 2020 


\section{NUSANTARA; Journal for Southeast Asian Islamic Studies Vol. 16, No. 1, Juni 2020}

sesajian yang dibawa ke tempat ritual sema rantau ini yaitu kepa kerbau yang tinggal tulang nya di bawah ketempat ritual yang terletak diperbatasan tanah ulayat antara desa tanjung beringin dengan desa gakah bertalut, disinilah tempat dilakukannya ritual sema antau tersebut.

Sema rantau ini menurut kepercayaan masyarakat terdahulu yaitu untuk menyampaikan pesan kepada penjaga sungai seperti buaya supaya tidak mengganggu masyarakat desa tanjung beringin. Penjaga sungai akan menyampaikan pesan atau menampakan diri juga sama seperti harimau, penjaga sungai menyampaikan pesan

atau menampakan diri apa bila masyarakat melanggar agama dan adat istiadat yang berlaku di masyarakat desa tanjung beringin seperti zina, berjudi, konflik di tengah masyarakat dan tokoh-tokoh masyarakat yang tidak lurus dalam menjalankan fungsinya seperti ninik mamak dan jajarannya.

Sema rantau ini merupakan prosesi terakhir dalam pelaksanaan sema nagari dan sema rantau, setelah di umumkan oleh dukun atau tokoh masyarakat kepada penajaga sungai supaya tidak menggangu masyarakat dan tegur lah ketika masyarakat membuat salah maka ritual ini akan ditutup dengan do'a bersama di perbatasan tanah ulay tersebut, supaya desa aman dan tentram dan silatuh rahmi berjalan dengan baik dan nilai- nilai gotong royong terjaga dan jugga sosial tetap bersatu dalam segi apa pun di desa tanjung beringin.

Siklus kehidupan masyarakat penuh dengan nilai-nilai dan norma- norma kehidupan yang tumbuh secara turun temurun. Nilai dan norma tersebut adalah untuk mencari keseimbangan dalam tatanan kehidupan. Hal tersebut dibentuk sesuai dengan kebutuhan masyarakat setempat yang akhirnya membentuk adat- istiadat. Dan adatistiadat diwujudkan dalam bentuk tata adat. Tiap-tiap daerah mempunyai adatistiadat sendiri sesuai dengan lingkungan setempat.

Seperti halnya pelaksanaan tradisi sema nagari yang dilakukan oleh masyarakat desa
Tanjung Beringin secara turuntemurun oleh nenek moyang sampai sekarang. ini tidak bisa dihapus begitu saja karena sudah mengakar dalam hati masyarakat. Bahkan mereka percaya akan terjadi sesuatu yang buruk jika tersebut tidak dilaksanakan.

Sebagian besar masyarakat tanjung Beringin memandang bahwa tradisi sema nagari yang telah dilakukan tersebut membawa perubahan ke hal yang lebih baik dalam aspek sosial. Perubahan itu dapat dirasakan dengan adanya kedamaian di dalam desa. Pelaksanaan tradisi sema nagari merupakan bentuk syukur dari masyarakat atas berkah yang telah Tuhan berikan. Nampaknya tradisi sema nagari di Desa Tanjung Beringin memang akan tetap dilaksanakan karena disamping sebagai ungkapan rasa syukur kepada Allah SWT, juga merupakan adat asli masyarakat Tanjung Beringin yang sulit dihilangkan begitu saja karena sudah dilaksanakan turun-temurun oleh sesepuh masyarakat Tanjung Beringin.

Antusias masyarakat Tanjung Beringin dan luar Tanjung Beringin sangat besar karena mereka datang dalam tradisi sema nagari dengan tujuan untuk menyaksikan bersama- sama . Setiap tahunnya antusias masyarakat meningkat dan semakin banyak masyarakat Tanjung Beringin khususnya dan masyarakat di luar Tanjung Beringin pada umumnya yang berminat untuk menyaksikan ritual adat sema nagari sema antau di Desa Tanjung Beringin.

Kebersamaan dan saling membantu sesama semakin dapat dirasakan oleh masyarakat Tanjung Beringin. Ini dapat dilihat dengan adanya pengumpulan dana untuk pengadaan sema nagari untuk pembelian hewan kerbau, dan mereka bekerja sama gotong-royong mempersiapkan segala sesuatu yang dibutuhkan demi lancarnya pelaksanaan tradisi tersebut.

Nilai tradisi sema nagari yang terdapat dalam kegiantan tradi yang dilakukan oleh 
masyarakat desa tanjung beringin yaitu:, ${ }^{17}$ Nilai Sosial; Nilai Moral; Nilai Kegotongroyongan Nilai Kerukunan / kebersamaan; Nilai Religi; Nilai Ekonomi; Nilai Estetika; Nilai Hiburan; Nilai Budaya.

\section{Persepsi Masyarakat Terhadap Munculnya Sema Nagari}

Menurut Bapak Falozen (seksi acara dan seniman dalam acara sema nagari, usia 41 tahun), sebagai warga masyarakat, beliau berpendapat bahwa Tradisi sema nagari harus tetap dilestarikan karena mengandung agama, adat, kesenian lokal (musik dan syair), sejarah kampung dan kerajaan rantau kampar kiri gunung sahilan, ini merupakan daya tarik dari sema nagari.

Menurut Indil Fitri, (ketua pemuda, usia 33 tahun), pendapat saya tentang Tradisi sema nagarisangat antusias, sangat mendukung sebagai bentuk pelestarian budaya, jadi harus tetap diperhatikan. Kegiatan seperti itu juga berdampak positif karena bisa menjalin rasa kekeluargaan terhadap masyarakat Tanjung beringin. Muda mudi Tanjung beringin diharapkan bisa terus berpartisipasi sebagai penerus.

Menurut Alexander, (mahasiswa tanjung beringin, usia 21 tahun), Tradisi sema nagari yang dipentaskan dalam upacara adat sema nagari Tanjung beringin sangat penting untuk dilestarikan karena itu adalah peninggalan nenek moyang sejak zaman Kerajaan Rantau Kampar Kiri Gunung Sahilan. Disisi lain Tradisi sema nagari itu untuk menunjang kebersamaan warga Tanjung beringin, selain itu juga sebagai rasa syukur atas kenyamanan masyarakat dengan terdiri tiga alam sehingga masyarakat tidak terganggung dengan mahluk-mahkluk lain dan juga silaturahim terjaga di antara masyarakat dan juga masyarakat lain.

Saya sebagai pemuda Desa Tanjung Beringin akan menjaga dan ikut berpartisipasi melestarikan kebudayaan Desa Tanjung

${ }^{17}$ Elly M. Setiadi dan Usman Kolip. Pengantar Sosiologi: Pemahaman Fakta dan Gejala Permasalaban
Beringin dan tentunya agar budaya, adat dan istiadat yang ada di Indonesia khususnya di Desa Tanjung Beringin tidak berangsur punah dan bilang ditelan zaman modern yang hampir sebagian pemuda sudab tidak peduli dengan kebudayaan itu.

\section{Pandangan Islam Terhadap Perkembangan Ritual Sema Nagari}

Sebagian besar masyarakat tanjung Beringin memandang bahwa tradisi sema nagari yang telah dilakukan tersebut membawa perubahan ke hal yang lebih baik dalam aspek sosial. Perubahan itu dapat dirasakan dengan adanya kedamaian di dalam desa. Pelaksanaan tradisi sema nagari merupakan bentuk syukur dari masyarakat atas berkah yang telah Tuhan berikan. Nampaknya tradisi sema nagari di Desa Tanjung Beringin memang akan tetap dilaksanakan karena disamping sebagai ungkapan rasa syukur kepada Allah SWT, juga merupakan adat asli masyarakat Tanjung Beringin yang sulit dihilangkan begitu saja karena sudah dilaksanakan turun-temurun oleh sesepuh masyarakat Tanjung Beringin.

Antusias masyarakat Tanjung Beringin dan luar Tanjung Beringin sangat besar karena mereka datang dalam tradisi sema nagari dengan tujuan untuk menyaksikan bersama-sama. Setiap tahunnya antusias masyarakat meningkat dan semakin banyak masyarakat Tanjung Beringin khususnya dan masyarakat di luar Tanjung Beringin pada umumnya yang berminat untuk menyaksikan ritual adat sema nagari sema antau di Desa Tanjung Beringin Kebersamaan dan saling membantu sesama semakin dapat dirasakan oleh masyarakat Tanjung Beringin. Ini dapat dilihat dengan adanya pengumpulan dana untuk pengadaan sema nagari untuk pembelian hewan kerbau, dan mereka bekerja sama gotong-

Sosial, (Jakarta: kencana prenadamedia grup, 2011) cet ke 1, hlm. 119 


\section{NUSANTARA; Journal for Southeast Asian Islamic Studies Vol. 16, No. 1, Juni 2020}

royong mempersiapkan segala sesuatu yang dibutuhkan demi lancarnya pelaksanaan tradisi tersebut.

Apabila ditinjau dari syari'at Islam, ritual sema nagari ini diperbolehkan karena terdapat maksud dan tujuan tertentu dari ritual sema nagari yang dilakukan oleh masyarakat Tanjung Beringin adalah sebagai ungkapan rasa syukur terhadap Tuhan Yang Maha Esa, selain itu juga dianggap masyarakat sebagai sarana membina solidaritas antar masyarakat dan terjaganya perilaku-perilaku yang bertentangan dengan agama dan adat istiadat yang berlaku di desa tanjung beringin. Apa yang dilakukan oleh masyarakat Desa Tanjung Beringin itu disebut bertawassul, yaitu berdoa kepada Allah melalui perantara.

Suatu realitas yang tidak bisa dihindari bahwa masyarakat muslim masih banyak yang melaksanakan ritual tradisi yang merupakan peninggalan nenek moyang yang dilatarbelakangi oleh ajaran-ajaran non Islam. Tradisi yang sudah menjadi budaya masyarakat itu serasa sulit untuk dihilangkan, terutama bagi masyarakat tanjung Beringin karena menyangkut masalah ketentraman hidup. Disamping punya kelebihan, tradisi sema nagari juga memiliki kekurangan, di antaranya:

Pertama, Apabila ditinjau dari segi syari'atnya bertentangan dengan ajaran Islam, karena ada beberapa bentuk sesaji yang dipersembahkan untuk roh-roh leluhur, itu merupakan salah satu perbuatan yang sangat dilarang agama terutama agama Islam

Kedua, Masyarakat merasa takut dan khawatir apabila tidak diadakan ritual sema nagari, akan mendatangkan malapetaka

Ketiga, Adanya masyarakat yang mempercayai harimau penjaga kampung merupakan wujud dari roh nenek moyang yang menjaga keselamatan warga kampong.

Keempat, Ditinjau dari ritualnya, sema nagari termasuk syirik karena ada sesaji yang maksud dan tujuannya ditujukan kepada roh nenek moyang, yaitu selain Allah.
Menyembah sesuatu yang selain dari Allah, termasuk syirik.

Syirik ialah menyamakan selain Allah dengan Allah dalam hal-hal yang seharusnya ditujukan khusus untuk Allah, seperti berdo'a meminta kepada selain Allah disamping berdo'a memohon kepada Allah. Barang siapa yang beribadah kepada selain Allah berarti ia telah meletakkan ibadah tidak pada tempatnya dan memberikannya kepada yang tidak berhak menerimanya.

Namun demikian, terdapat aspek positif dari ritual Sema Nagari Desa Tanjung Beringin ini, yaitu; Pertama, Sabagai sarana memperkuat persatuan dan kesatuan. Tradisi sema nagari di desa Tanjung Beringin tidak hanya dihadiri oleh masyarakat setempat, namun juga dihadiri oleh masyarakat sekitar. Mereka berbaur menjadi satu tanpa ada pembedaan status sosial ataupun asal.

Kedua, Merupakan kegiatan mempertahankan warisan nenek moyang. Banyak warisan nenek moyang yang sudah terabaikan oleh masyarakat, Padahal kalau kita menyadarinya banyak hikmah didalamnya yang terkait sekali dengan kehidupan, baik manusia sebagai makhluk individu, sosial atau dalam hubungan dengan Yang Maha Kuasa.

Ketiga, Berdampak positif dalam bidang ekonomi, karena perekonomian masyaraka Tanjung Beringin menjadi lancar terutama dari segi perdagangan dan pertanian. Lebih memperoleh kelancaran dalam bertani, dan dipermudah dalam berdagang.

Keempat, Dengan diadakannya ritual sema nagari ini, masyarakat merasa kehidupannya menjadi lebih rukun, tentram dan bisa mempererat tali persaudaraan dan kegotongroyongan masyarakat. Terjaganya adat istiadat yang berlaku di masyarakat dan terhindar dari perbuatan- perbuatan yang bertentangan dengan agama islam. 
Indra Sari, dkk: Ritual Sema Nagari...

\section{Kesimpulan}

Prosesi dalam pelaksanaan ritual sema nagari di Desa Tanjung Beringin berawal dari nazar masyarakat kepada Allah, nazar terseut yaitu jika tidak terjadi bala atau bencana dan tidak konflik di antara masyarakat maka pada tahun berikutnya akan disembelih satu ekor hewan kerbau dan ziara kuburan.

Dalam prosesi ritual sema nagari yaitu Pemotongan kerbau dilakukan oleh segenap jajaran adat istiada kenegerian malako kociak yaitu Ninik Mamak, Dubalang Suku dan masyarakat yang membantu, pemotongan kerbau ini dilakukan sehari sebelum prosesi ritual dilakukan. Dan Perahu hias ini merupakan salah satu alat atau sara untuk melaksanakan ritual sema nagi, proses pembuatan perahu hias ini dilakukan dengan gotoroyong bersama pada malam sebelum melaksanakan ritual sema nagari. Sampan hias ini untuk alat trasportasi Kerajaan Rantau Kampar Kiri, Ninik Mamak, dan Pemerintah Desa.

Pada hari puncak acara ritual dimulai dari ziarah kubur. Ziara kubur terdiri dari dua makam yaitu Datuk Dara Putih yang merupakan orang pertama yang tinggal di desa, yang kedua kubur dukun hari dan di kuburan dukun ini lah sesembahan ritual di tinggalkand dan ziara kubur ini disebut sebagai ritual sema nagarai. Setelah ziara kuburan ini selesai langsung dilanjutkan dengan ritual sema rantau, sema rantau ini sesembahannya tengkorak kerbau yang telah disembelih yang di bawa keperbatasan desa (batas ulayat), sebagai tanda batas wilayah dan sebagai bentuk komunikasi masyarakat dengan penghuni sungai agar tidak mengganggu masyarakat seperti buaya dan lain sebagainya dan ritual ini terakhir dari prosesi sema nagari.

Nilai-nilai yang terkandung dalam kegiatan sema nagari ini sangat banya karena kegiatan sema nagi ini dilakukan oleh seluruh masyarakat yang ada di desa dan juga dari luar desa. Dari kegiatan ini nilai-nilai yang terkandung yaitu pertama nilai sosial, masyarakat akan terjadi interaksi timbal balik antara individu dengan individu lainnya sehingga memunculkan suatu tatanan sosial yang harmaonis, Kedua nilai moral merupakan ajaran tentang hal yang baik dan yang buruk, yang menyangkut tingkah laku dan perbuatan manusia. Ketiga nilai gotong royong. Keempat nilai kerukunan, Kelima nilai religi, Keenam nilai ekonomi, nilai estetika, nilai hiburan dan nilai budaya, nilai-nilai ini lah yang ada pada kegiatan sema nagari de desa tanjung beringin 


\section{DAFTAR PUSTAKA}

Abdulkadir Muhlmammad, Ilmu Budaya Dasar, Jakarta: Cv Fajar Agung, 1992, Ed. 1, Cet. Ke-3.

Adeng Muchlmtar Ghlmazali, Antropologi Agama; Upaya Memahlmami Keragaman Kepercayaan, Keyakinan dan Agama (Cet. I; Bandung: Alfabeta, 2011).

Bustanuddin Agus, Agama Dalam Keblmidupan Manusia; Pengantar Antropologi Agama, Jakarta, Pt RajaGrafindo Persada, 2006.

Dadang Kahlmmad, Sosiologi Agama (Bandung. PT. Remaja Rosdakarya, 2000).

Departemen Agama RI., Al-Qur'an Dan Terjemabnya (Surabaya: Mekar, 2004).

Eko Digdoyo, Ilmu Sosial Dan Budaya Dasar, Bogor, Ghlmalia Indonesia, 2015, cet. ke- 1.

Elly M. Setiadi dan Usman Kolip. Pengantar Sosiologi: Pemahaman Fakta dan Gejala Permasalahan Sosial, (Jakarta: kencana prenadamedia grup, 2011).

Elly M.Setiadi, dkk, Ilmu Sosial Dan Budaya Dasar, Jakarta, Kencana PrenadaMedia Group, 2006.

Jamaluddin Kafie, Tuntutan Pelaksanaan Rukun Iman Islam dan Ikhsan, (Surabaya: Penerbit Al-Ikhlas, 1997).

Koentjaraningrat, Metode-metode Penelitian Masyarakat (Jakarta, Gramedia, 1981)).

Muhammad Yusuf Musa, Islam Suatu Kajian Komprehensif, (Jakarta: Rajawali Pers, 1988).

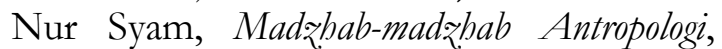
Yogyakarta: LKis, 2009, Cet. ke-2.
Prof. H.A.Djazuli. Kaidah-Kaidah Fikih Kaidab Hukum Islam Dalam Menyelesaikan Masalab Praktis. (Jakarta: Putra Grafika, 2006), Cet. 6.

Rusmin Tumanggor dkk, Ilmu Sosial Dan Budaya Dasar, Jakarta: Kencana Prenada Media Group, 2012, Ed. Revisi, Cet. Ke-2.

Wawancara dengan Bapak Ajismanto (Ninik Mamak Pucuk Adat), Jum'at, 7 Agustus 2020 bertempat di Kediaman.

Wawancara dengan Bapak Yusuf (Keturuan dukun harimau), Kamis, 13 Agustus 2020.

Wawancara dengan Ibu Koluik (Keturuan Dukun Harimau), Jum'at, 14 Agustus 2020. 